\title{
THE SUPERIORITY OF TRAVEL MOTIF IN AZERBAIJANI EPIC FOLKLORE
}

\author{
Nurana Orujova \\ Azerbaijan National Academy of Sciences Folklore Institute, Baku, Azerbaijan \\ https://orcid.org/0000-0001-9777-6822
}

DOI: https://doi.org/10.31435/rsglobal_wos/28022020/6914

\begin{abstract}
ARTICLE INFO
Received: 18 December 2019

Accepted: 17 February 2020

Published: 28 February 2020

\section{KEYWORDS}

Motif concept, travel motif, structure, movement dynamic, dream.

ABSTRACT

The plot structure of the epic folklore samples consists of the logical order of the different motifs so that there the travel motif is characterized with its domination and serves to certain purposes. At the article the dream, the almond-shaped pattern that attracted to reach as myfogeographical location and conditioned it getting direction "cosmos and chaos travel motive was exlained at the context. Folklore expressions created by each nation are unique and they inform about national psychology being rooted in the mythical mind of that nation as a code. And it is not secret that although there is uniqueness, there is the plot that makes nation closer to each-other, its components and motives.
\end{abstract}

Citation: Nurana Orujova. (2020) The Superiority of Travel Motif in Azerbaijani Epic Folklore. International Academy Journal Web of Scholar. 2(44). doi: 10.31435/rsglobal_wos/28022020/6914

Copyright: (C) 2020 Nurana Orujova. This is an open-access article distributed under the terms of the Creative Commons Attribution License (CC BY). The use, distribution or reproduction in other forums is permitted, provided the original author(s) or licensor are credited and that the original publication in this journal is cited, in accordance with accepted academic practice. No use, distribution or reproduction is permitted which does not comply with these terms.

Introduction. Motif that doesn't have a special meaning in separate, has symbolic significance within the text and plays a dominant role in the formation of other literary components stands at the stimulating position in human mind and it is any detail that regulates it by stimulating the coherent and logical sequence of events in the structure of art work that is the product of this mind. Diversity of artistic elements stipulates the formation of various motives that differ from each other.

Each field has its own motif and driving force that they also establish the models of ideas serving to specific purposes of this field. Motif focuses on and unites the elements that are isolated from each-other and scattered under an entire name and appears in the same sense with it by coordinating it with the subject. Motif also includes artistic image, expression in the narration and other elements of the text such as sound and physical movements. It is determined being symbolized by means of the theme that shows itself in an abstract form. At the same time, motif which is the simplest and straightforward part of the plot is used for the description of individual details of the work. Of course, there is a key -major motif in the plot structure of each work and it is directly related to the idea that will be delivered in the work. Structural components of a whole text can show itself in an artistic motive. Similarly, a motif can condition a new motive. First of all, there should be a reason that conditions it for the formation and occurrence of any motif in artistic work.

Travel motif is a space of motives that tightly connects and links historical thought with epic tradition. Of course, the mentioned motif bearing historical nature, is the historical source in order to ascertain the social, political and religious views, psychological and cultural sphere of ancient Turks. This is such an element that it should absolutely show itself in any behavioral style and action. Motif bears an informative nature, it directs this or that information either from plot to plot or from expositions within plot to final as codes. In this regard, travel motif is a poetic way, direction and method.

It, being mainly a motif that is often found in voluminous epic genres - tales and sagas, is characterized by its dominance in conditioning other motives. Travel about which researchers mention episodically - is a motif that has specific semantics and which relates to Turkish mythological way of thinking until Islam, and on the other hand, to mystical views. And this directs the motif to be analyzed by approaching it from social, mythological and individual aspects. 
First of all, the position of travel in the plot structure of epic works and its meaning as lexical idiom is thought-provoking. Though it is impossible to express opinion about the specific time of the advent of motif in the epic genre, it is possible to speak about its early evolution in the plot and stable position as the required motif. In ancient times people were able to establish primitive motifs in early artistic creativity or separate details were not in the form of perfect motifs. Travel motif as an ordinary detail was firstly formed in mythical view of people. This, first of all, was the result of the search for truth being a system of initial impressions of ancient people about the world. So, every ethnicity created myth-poetic word before laying the foundation of civilized culture and formed the model of mythical world. Just for that reason while investigating the position of any motif in the epic genre, we should not forget that its history is filtered through mythical thinking.

If we will look at the history, in this case, we can see that travel has become a tradition in the background of national interests, diplomatic and aggressive relations after the establishment of class society. The primary reason that takes primitive man from one place to the other one was its food search. Formation of tribes, their being separated into various ethnic groups and moving to new places and historical flow of ethnic groups to other areas laid the foundation of the formation of a single plot and motifs. Then either great conqueror Alexander's conquest, Arab conquests or crusades increased the number of political visits, and this, in its turn, affected oral poetic language.

The religion of Islam and Islamic thought had great role in strengthening of the structure of epic text by travel motif's being widely spread. Although the mentioned motif existed in "Jahiliyyah" era (Period of Ignorance), it was purely widely spread after the restoration of Islam. So, the travels of Prophet Muhammad (p.b.u.h) and his followers, Imams and the Khalifahs for the reasons such as spreading Islam etc. are the indicators of the fact that ancient people had enough knowledge about travel. Saying of Prophet Muhammad "Travel, visit, be healthy, earn daily bread" [6,119] once more confirms our opinions.

Travel motif in epic folklore examples can be classified as follows:

1. According to the form of realization: When we say the form of realization, we mean the ways by which trips or visits are realized. If we will take into consideration the directions of travels, the following ways can be referred to this form:

a) Travels realized by arming oneself and going on horseback. This is a form of travel motif that is clearly visible in the first reading of text. Undoubtedly, horse is always given as a friend, brother and helpmate of hero in Turkish mythical thinking and by means of it contact is established between two worlds - dark and light world, chaos and cosmos. And in most times, horse is given to a hero who is travelling alone as a gift by respected person, a wise man or father. And this is a sign of the power of horse and its ability to shorten long distances that is acting as a savior of the hero.

b) by means of dream. As dream retains its relevance for centuries, it is being enough investigated by folklore scholars even today. Dream which is rooted either in the content or myth-poetic structure of the text is an important detail in travelling and it requires special investigation. No any detail being spontaneous in folklore text, plays a certain role in the course of events. This motif sometimes playing major, and sometimes episodic role in several genres, mainly, shows itself in tying a knot at the events. Dream has transition function between chaos and cosmos being a form of expression of individual's identity. Dream in itself being a psychological events, is a fact necessary from physiological point of view with which person meets every day. It fulfills the function of transition between this and the other world. To sleep at night embodies darkness, and to wake up at daytime personifies light. If we will accept darkness as death and light as life, in this case, here we should again note that mythological- ritual initiation is at the leading role. If dream fulfills transition functions either between chaos and cosmos, or death and life, so it means that here travel motif is hidden in the sub-text. The Oghuz people didn't vainly called dream as "short death". Verse 42 of Surat al-Zumar of Holy Guran it is guided: God gets the souls [spirits) of those (whose end is near) while they are dead, and the souls of those who are not died (whose end is not near) in dream (as dream is also a thing like death, connection of spirit with body is interrupted during sleep). The souls of those who were sentenced to death are kept (in the world of spirits) (their spirits will not return to bodies, so the body will also die). And will return the souls of others (who are not sentenced to death) for a certain period (to their bodies when they wake up until their doom will come). Bringing Guran's verses into epic text and references made to it requires a special investigation. And the power of influence of the above- mentioned verse in folklore texts is clearly visible. Travel by means of dream can be characterized as travelling through eyes. Dream being before and after travel collects a number of specific features in itself. Both of them hero fell asleep deeply. Hero's falling asleep has more poetic content in love eposes. Falling asleep is a little bit different in love eposes, if we will say that it comes from 
the requirement of the motif of following bud, we wouldn't be wrong. In our opinion, following budis also a ritual, and it creates necessity for travelling. In eposes that are based on love, Lover (lover) will know its beloved either by following budor by the tradition of cutting umbilical cord. And in a group of eposes heroes fall asleep during travel and near the spring. They find a sign on them belonging to their lovers when they wake up and travel following this sign in order to reunited with her. Lover falls asleep deeply and no one can wake him up. Experienced persons, mainly, the old women state that they are budded. When hero wakes up, he wants immediately to be reunited with his lover girl. Other girls will be shown to lover in order to forget this love. However, lover will not return back from his way of love, though he faces with a number of difficulties, it will prove that he is a lover of truth. Budding awakening interest in listener, makes it to follow the plot of the work till the end and the lovers budded in dream will come together at the end.

c) By means of wells. In particular, in love eposes we often see that lover is thrown to well. Sometimes this well, being full of with poison makes the position of hero more difficult. Well bears the function of transition. This transition is between death and life, chaos and space. For example, in the epos of "Abbas and Gulgaz" Abbas's being thrown to well for twice and rescued by the holy power, in the part "Koroghlu and Bolubey" in "Koroghlu" epos, the named hero's being thrown into the well and his being rescued by one of the characters - Isabali is the proof of what we are talking about. Of course, we can enlarge this list: "Tahir and Zohra", "Seydi and Pari", "Shah Ismail" etc. This detail is also reflected in our tales as in eposes: "Malikmammad", "The tale of Hatem" etc.

Well represents the transition from chaos to space or vice versa in a micro level.

d) By means sea and spring. Heroes mythically take a trip by this way in our tales such as "Shamsh and Gamar", "The golden ram", "Okhay and Ahmed", "Tapdig" etc.

2. According to its purpose: As we have mentioned above, the purpose is important in every travel. This conditions the end of travel. Travels or trips can be divided into 3 groups according to their purposes:

a) the travel done by lover in order to come together with his beloved;

b) military travels or journeys that reflect some certain social conflicts;

c) travels done for hunting; sometimes the last type of travels creates necessity for the abovementioned (items a and b) travels. So, in some cases, hero falls in love with the beautiful girl during his travel and leaves his homeland in order to come together with her. (This, that's, hero's leaving his homeland depends on where the girl is.) First type of travel can be mostly found in love eposes, tales, and the second type of travel are found especially in heroic eposes, and the third type of travel can show itself in all voluminous genres of epic type. It is possible to meet all three types $(a, b, c)$ of travels made according to purpose in a complex way in a number of our eposes.

3. According to the subject of the hero who is travelling: during these investigations every work and its main character should be treated individually. So, while characters who are travelling in the epic of "The Book of Dede Korkut" belong to high class, in "Koroglu" epos, except pashas, Koroghlu and his fellows don't belong to this class. However, the representatives of both classes who are travelling can be found in love eposes and tales. Here, persons who financially have less opportunities, working lovers' falling in love with the daughters of rich families or pashas and beys and achieving to their goals by their mind and skills are described. As the intention is different on travelling in love and heroic eposes, the problems faced by those characters are also different.

4. And travels can be divided into two groups being horizontal and vertical according to their directions. Here, vertical travels are mythical visits reflected in sub-layers of the text.

5. According to the space of realization; It is also necessary to clarify and investigate the spaces where it gets direction in order to obtain comprehensive knowledge about the motif. If we will approach this space from myth- geographical point of view, we should divide it into two poles being space and chaos. Both of them reflect a specific society. More precisely, chaos doesn't show itself in a specific space or world outlook. If we will say that "chaos is over and it stayed in the past, and the space is today", we would be wrong. Plot of each epic work is formed from the combination of chaos and cosmos. There is a polishing process within the plot and this leads to a neat layout-space at the end. In our opinion, chaos is essential and primary, space is derivative. Chaos exists previously, and it is possible to restore cosmos at any time in various spaces. If we will say it in a somewhat poetic form, in this case, cosmos can be considered as a moonlight at dark night. Character who is in search of lost hopes plans to travel in constant ideal spaces (cosmos). Realist hero clearly seeing the conflicts of the society is also an emotional individual. He is able to make "an imaginery trip" to any space. Travel to chaos is possible both by means of dream and mounting on a horse. However, here one point raises a question. A hero who is armed with mounting on a horse falls asleep as soon as reaching to space - chaos where he travels. This occurs infalling asleep, usually, in the transition of chaos and space. It can be conditionally 
called transition within transition. It means that one travel conditions the other one in the top of the text, if the demand will be increased for it, one transition in sub-text or myth-poetic plan conditions the other one. Doctor of Philology S. Rzasoy calls chaos the world of sleep and death. Of course, it doesn't mean real death, if there is death in mythology, there is also return to life. "To be asleep is to be in the world of death and to be in the world of death is to be asleep" [5,192]. This death and resurrection is possible only with the initiation ritual. Death and resurrection of hero in epic plot has three types:

1. As the space of the travel done by the hero who goes to chaos is a dark world, he should willingly or unwillingly pass the initiation process. This is being more common, refers to all heroes. And again returning to space means its resurrection.

2. Travel to chaos is possible by means of dream. In this case, hero falling asleep is in the status of death. After waking up, he will be alive. Therefore, sleep is called "short death" by the Oghuz people. This process bears an individual character. So that, not each hero travels to chaos by means of dream. However, we should mentioned a point that if one hero travels chaos by means of both mounting on a horse and also dream, in this case, it means the hard trials that wait for him. Again to be dead in the status of dead points out that the transition to status of being alive is very hard beforehand.

3. The ritual of initiation sometimes occurs by means of neither dream nor mounting on a horse in epic work. In the text that bears a special interest in itself: a hero who successfully has passed tests and rescued from difficulties hears unexpected news during the moment of marriage in cosmos. The character that is in the position of death is awakened with talisman. The mentioned process is mostly found in tales.

6. Classification according to mythical- mystical and religious views that underlie this motif.

7. According to the dynamic of movement: Travel, along with being selected with its historical antiquity, is a motif of the plot structure of work that is permanently significant in its evolutionary process. If we will look at the dynamic of movement of motif, we can conditionally divide it into 2 groups being active and passive: Activity-being closely related to the preference of the traditions of epos creativity over the old-mythological views, comes from its standing at the important position within the epic plot. During passive reflection, it is necessary to "mythically travel" the sub-layer of the work in order to reveal details and secret mythical rituals sourced from early thinking. And this is noticeably more later during the initial review and it is reflected not in external signs of events, but in its essence and core.

We can call the reasons and aims that condition the necessity of travel motif as the algorithms of motif. So, the followings can be included in the general semantics of travel motif:

1. Travel motif being closely related to the idea that is delivered in the work, creates necessity for its final.

2. The essence of travel and the problems occurred directly depend on the power of reflection of truth by the set aims.

3. In most cases, it is turned into a necessary and required detail in achieving the purpose.

4. It doesn't reflect specific time in itself.

5. It plays a role in the formation of heroic character.

6. It is embodied as the search of loft hopes of a person.

7. It is reflected with certain rituals.

8. It is, being a leading motif, non-identical in several genres.

9. It is in the process of historical evolution.

10.Majority of travels depend on the conflicts within plot.

Conclusions. So, the conclusion is that to leave the house and to go to any place doesn't mean to travel. The way overcome by hero in necessary or accidental cases, planned beforehand, or suddenly leaving its homeland and again to his house within the certain periods is called "the travel way" in epic text. This travel that has large-scale map is full of with various adventures and challenges. So, in order to comprehensively investigate the burden of travel motif in the text, it should be involved in the investigation and research from various aspects.

\section{REFERENCES}

1. Azerbaijani eposes, volume II, Baku: “Chirag” Publishing House, 2005

2. Azerbaijani eposes, volume III, Baku: "Chirag" Publishing House, 2005

3. Azerbaijani eposes, volume IV, Baku: "Chirag" Publishing House, 2005

4. Masterpieces of the Literature of Azerbaijan, Tales, Writer, 1985.

5. Seyfaddin Rzasoy, Themythology of Oghuz, Baku: "Nurlan", 2009, p.363

6. O. Qudratov, N. Qudratov. Prophet Mohammad: His life and sayings. Baku-1990 